\title{
TRANSUMANISMO E PÓS-HUMANISMO: UMA APROXIMAÇÃO ÉTICO-TEOLÓGICA
}

\author{
Transhumanism and Posthumanism: an Ethical and Theological Approach
}

Erico Hammes *

RESUMO: O presente artigo pretende recolher elementos teológicos para uma relação entre a Teologia cristã, transumanismo e pós-humanismo. Enfoca especialmente os temas da natureza humana e da Ética Teológica, ante a importância que adquiriu o movimento trans- e pós-humanista no ambiente científico e tecnológico. A partir de uma descrição histórica dos conceitos identifica-se o transumanismo como momento da aplicação massiva dos recursos da ciência e da técnica para a melhoria e aumento (enhancement) das condições e das capacidades humanas. O pós-humanismo, por sua vez, representa o resultado, na forma de uma nova condição de ser, qualificada como pós-humano. Mostra-se, num segundo momento, com recurso a K. Rahner, como a natureza humana, em seu sentido antropológico, se revela capaz de transformações, desde que se mantenha sua qualidade essencial de autonomia, relacionalidade, liberdade e responsabilidade diante do Mistério Divino. No terceiro momento, mostram-se algumas exigências éticas para uma avaliação do trans- e pós-humanismo.

PALAVRAS-CHAVE: Transumanismo. Pós-Humanismo. Natureza Humana. Antropologia Teológica. Pessoa. Ética.

ABSTRACT: This article aims at gathering theological elements to build a relationship between Christian theology, transhumanism and posthumanism. It focuses mainly on issues of human nature and theological ethics to address both transhumanism and posthumanism, movements that have acquired importance in the areas of science and technology. First, a historical description of the concepts

\footnotetext{
* Pontifícia Universidade Católica do Rio Grande do Sul, Porto Alegre, RS, Brasil.
} 
help identify transhumanism as the movement during which a massive allocation of scientific and technological resources was applied to improve and enhance human conditions and abilities. Posthumanism is the result of that first movement, a new condition of being qualified as posthuman. Then, based on K. Rahner, we will show how human nature, in its anthropological sense, is able to transform itself, as long as it keeps its essential quality of autonomy, relationality, freedom and responsibility before the Divine Mystery. Finally, the article points to some ethical requirements for an assessment of both trans-and posthumanism.

KEYWORDS: Transhumanism. Posthumanism. Human Nature. Theological Anthropology. Person. Ethics.

\section{Introdução}

$\mathrm{B}_{\mathrm{in}}^{\mathrm{a}}$ asta uma simples pesquisa de internet para dar-se conta do volume de informações de boa qualidade a respeito do tema Pós- e Transumanismo tanto em sites como em jornais e magazines. Uma busca em alguns bancos de dados revela considerável número de publicações em periódicos científicos especializados, também na área de Teologia. Assim, enquanto o Portal da Capes para os descritores Teologia e Trans- ou Pós-humanismo registra 13 ocorrências, o Index Theologicus registra 55 títulos de publicações contendo entre as palavras-chave o conceito de Transumanismo desde o ano de 2002. Alguns periódicos teológicos, como as francesas Foi $\mathcal{E}$ Vie, 2014 e Revue d'éthique et de théologie morale, 2015, as americanas Theology and Science, em 2015, Dialog: A Journal of Theology, em 2015, e Zygon: Journal of Religion and Science, em 2012, dedicaram números especiais ao tema do pós- e transumanismo, além de vários artigos esparsos e quantidade considerável de recensões de obras. ${ }^{1}$ Um levantamento mais rigoroso nas referências disponíveis revela um incremento significativo nos últimos anos e uma convicção crescente para uma aproximação entre Teologia, pós- e transumanismo.

A dificuldade do tema trans- e pós-Humanismo começa com a identificação de sua natureza. Trata-se de uma corrente de pensamento, de uma ideologia, de uma religião ou de uma tecnologia? De certo modo é tudo isso, mas

\footnotetext{
${ }^{1}$ Para uma visão geral e introdutória sobre o transumanismo e pós-humanismo em português, pode ver-se FERRY, L. A revolução transumanista; BOSTROM, N. Superinteligência: Caminhos, perigos, estratégias, além de alguns artigos esparsos em periódicos; em espanhol, HOTTOIS, G. ¿El transhumanismo es un humanismo?. Além disso, vários dos principais nomes e movimentos associados têm sites próprios: A Associação Transumanista Mundial (WTA) mantém o site Humanity Plus https://humanityplus.org com textos referenciais como a Transhumanist Declaration, um longo texto explicativo de perguntas frequentes, Frequente Asked Questions (FAQ) e informações atualizadas sobre o tema; a Home Page de Nick Bostrom https://nickbostrom.com/ oferece rico material do próprio autor; e a Singularity University https://su.org/ orientada especialmente para a inovação com os recursos atuais da ciência e tecnologia.
} 
não sempre com os mesmos sujeitos. Algumas perguntas que se podem colocar inicialmente: Qual é sua relação com o Humanismo e com o ser humano? Em que medida vai impactar a condição humana? Como pode ser pensado religiosa, cristã e teologicamente? Quais são as implicações éticas?

A intenção do presente artigo é oferecer uma abordagem introdutória da questão conceitual e dos aspectos ético-teológicos presentes em algumas das publicações mais recentes e com breve recurso a Karl Rahner. Inicia-se com uma aproximação conceitual dos termos transumanismo e pós-humanismo em sua relação com o humanismo, para num segundo momento considerar um dos temas fundamentais, a natureza humana e refletir por fim alguns aspectos ético-teológicos. Trata-se de uma apresentação muito mais descritiva do que analítica ou crítica. Na escolha da literatura, privilegiaram-se os textos teológicos cristãos históricos. Assim as tradições orientais e os Mórmons, que têm uma afinidade significativa, não foram levadas em conta. De modo semelhante, ficam sem atenção especial as obras críticas dos chamados "bioconservadores", especialmente Francis Fukuyama (2003), Michael Sandel (2013) e Jürgen Habermas $(2004)^{2}$.

Tomando como ponto de partida o número temático de Theology and Science, em que autores cristãos de várias confissões se manifestaram a respeito do transumanismo (Theology and Science v. 13, n. 2, may 2015), com destaque para o artigo orientativo de Ted Peters (2015), bem como os roteiros básicos de três obras recentes (FERRY, 2018; GÖCKE, 2018; MEIER-HAMIDI, 2018; HOTTOIS, 2016a) é possível mapear as principais perspectivas teologicamente relevantes para uma aproximação ao Pós- e Transumanismo. De um ponto de vista humanista secular, seguindo Luc Ferry (2018), percebe-se a necessidade de esclarecer os conceitos, registram-se os debates entre "bioconservadores" e bioprogressistas, as questões relativas à inteligência artificial e internet, bem como os problemas de regulação. Na perspectiva teológica e cristã a obra organizada por Benedikt P. Göcke e Frank Meier-Hamidi, com o sugestivo título de "Objeto de projeto: ser humano (Designobjekt Mensch)", é provavelmente a mais abrangente no gênero. ${ }^{3}$ A seu lado, uma terceira obra, de Gilbert Hottois, bioeticista, se dedica às implicações para a Bioética (HOTTOIS, 2016a, edição francesa, 2014). ${ }^{4}$

\footnotetext{
${ }^{2}$ Para uma aproximação do pensamento desses autores o artigo Murilo M. VILAÇA e Maria C. Marques DIAS. Transumanismo e o futuro (pós-) humano (2014). Pode ainda ver-se a obra coletiva, H.: transhumanism and its critics [sic!] de HANSELL et al. (2011).

${ }^{3}$ Especificamente em perspectiva católica, podem ver-se ainda Terence L. Nichols (Radical Life Extension, in: (MAHER; MERCER, 2009, p. 133-144), o artigo de Brian P. Green, no fascículo mencionado de Theology and Science (GREEN, 2015). Sandra A. Ham em artigo posterior faz uma crítica a vários dos artigos desse fascículo e defende a espiritualidade como uma relativização necessária de tendências transumanistas cristãs (HAM, 2016).

${ }^{4} \mathrm{O}$ original francês, La révolution transhumaniste, de 2016, traz como subtítulo Comment la technomédecine et l'uberisation du monde vont bouleverser nos vies. Trata-se do tema abordado no capítulo III por sua implicação nas condições do trabalho questionando se é um possível "eclipse do capitalismo ou desregulamentação selvagem" (p. 81-124).
} 


\section{Conceitos e Natureza do Trans- e Pós-Humanismo}

Introdutoriamente convém olhar a análise da dimensão religiosa secularizada do Transumanismo feita por Hava Tirosh-Samuelson no fascículo acima citado de Zygon (TIROSH-SAMUELSON, 2012, p. 710-734). Logo no início, ainda no resumo, qualifica o Transumanismo, enquanto movimento intelectual, como numericamente pequeno, cujas ideias, no entanto, "exercem profunda e ampla influência na cultura e sociedade atuais" (p. 710). Recorrendo a diferentes estudos e pesquisas pessoais propõe-se a mostrar o transumanismo como uma fé secular" que "por um lado, seculariza motivos religiosos tradicionais, e por outro, concede à tecnologia um sentido salvífico" (p. 719). Trata-se de uma religião sem revelação, mas que funciona como religião, com símbolos apropriados e uma certa afinidade com novos movimentos religiosos. Destaca, além disso, a explícita afirmação de setores transumanistas em favor de uma religião substitutiva ou de uma não incompatibilidade com religiões tradicionais. Em base aos diagnósticos em favor de uma sociedade pós-secular, com destaque para os esforços de J. Habermas em favor do papel da religião na esfera pública, a Autora, sublinha os traços escatológicos do discurso transumanista e sua forma peculiar de reencantamento religioso (p. 734).

Pós-humanismo e transumanismo, antes de serem uma simples questão de ciência e tecnologia, são, portanto, filosofias, crenças, religião, e mesmo teologias. Enquanto o livro A Cyborg Manifesto (HARAWAY, 2017, p. 1-90), originalmente publicado em 1985, pretende ser uma espécie de blasfêmia, portanto sob um pano de fundo religioso, a Declaração Transumanista (Transhumanist Declaration), originalmente formulada em 1998, está exarada sem referências religiosas, mas com forte apelo ético. Já o artigo de Max More (1990) havia qualificado explicitamente a religião como uma das "velhas estruturas" que mantém a humanidade em atraso e precisa ser superada. A razão para a persistência do fenômeno religioso seriam estruturas residuais do cérebro que até há uns 300 anos tinham uma função explicativa e tecnológica pré-científica. No passado a religião era uma fonte de sentido, de orientação e expressão de sentido, um meio de controle social (fundamento para as autoridades), justamente em consequência da estrutura do cérebro daquelas populações (p. 6). Quanto aos aspectos filosóficos, num primeiro momento, o site correspondente ${ }^{5}$ descreve o transumanismo como um "movimento vagamente definido, que se desenvolveu gradualmente ao longo das duas últimas décadas [sem precisar as datas]". Em base ao artigo já citado de Max More, o site qualifica o transumanismo como "uma classe de filosofias de vida que buscam a continuação e aceleração da evolução da vida inteligente

\footnotetext{
${ }^{5}$ Cf. https://humanityplus.org/philosophy/ .
} 
para além de sua forma e limitações humanas atuais pelo recurso à ciência e tecnologia, guiada por princípios e valores de promoção da vida" (MORE, 1990).

Ao lado dos dois conceitos principais no ambiente pós-humanista - Transumanismo e Pós-Humanismo - eventualmente se mencionam também Anti-Humanismo, Meta-Humanismo e mesmo Pós-Pós-Humanismo. ${ }^{6}$ Dado o uso, frequentemente intercambiado dos dois termos principais, para os efeitos do artigo, é necessário buscar uma delimitação adequada a fim de se poderem discutir as questões pertinentes.

\subsection{Transumanismo}

Transumanismo consiste na aplicação dos diferentes recursos disponíveis no âmbito da tecnologia e das ciências para superar os limites da condição humana, seja quanto à saúde, à idade e à inteligência ou ao conhecimento. Ilustrativamente pode citar-se a definição de Nick Bostrom (2005) para quem o transumanismo é "um movimento vagamente definido que se desenvolveu nas duas últimas décadas [i. é, desde 1985]." ${ }^{7} \mathrm{Na}$ descrição do que seria o transumanismo vai mencionando a aplicação de recursos como a nanotecnologia, suplementos alimentares, medicações, inteligência artificial (IA). Podem acrescentar-se a esses fatores, a robótica, os big dat $a^{8}$ as possibilidades de manipulação do DNA humano, facilitada pela descoberta do CRISPR-Cas) ${ }^{9}$ e as atuais possibilidades reais de estender a expectativa de vida. Numa palavra, trata-se de aumento (enhancement) e melhoria de possibilidades humanas nos diferentes âmbitos e capacidades. O termo inglês, enhancement, de acordo com Michael Bess, pode ser definido em sentido amplo como "uma intervenção destinada a modificar traços de uma pessoa, acrescentando qualidades ou capacidades que de outro modo não se esperariam caracterizar essa pessoa" (BESS, 2010, p.

\footnotetext{
${ }^{6}$ Além dos artigos em diferentes sites de Internet, especialmente Nick BOSTROM (2011), a primeira seção da obra de Luc FERRY (2018, p. 1-11) oferece uma breve descrição. Para a expressão "Pós-Pós-Humanismo" (ZABOROWSKI, 2017, p. 269).

7 Ted Peters (2015, p. 132-133) relaciona os transumanistas à "tecnociência e Filosofia que busca empregar tecnologia genética, tecnologia da informação e nanotecnologia para ampliar significativamente a extensão da vida saudável das pessoas, aumentar sua inteligência e tornar a nós humanos mais felizes e virtuosos".

${ }^{8}$ Designam-se geralmente com o nome Big Data, os dados, informações globais coletadas, armazenadas e geridas e disponibilizadas por gigantes da informação. Permitem virtualmente o controle e a vigilância da vida de bilhões de pessoas usuárias das plataformas de comunicação cotidiana.

9 Tecnologia muito recente de manipulação genética "simples" e barata em qualquer ser vivo, inclusive os humanos, o que, a quanto se sabe, já foi tentado. Por suas consequências imprevisíveis existe uma tentativa de regulação científica mundial, mas dificilmente vinculante. Teoricamente qualquer mudança, dependente da genética, poderia ser realizada. As implicações éticas são óbvias.
} 
643). ${ }^{10}$ Segundo alguns representantes do transumanismo em um futuro não tão distante será possível pensar na ruptura definitiva das fronteiras da morte, da doença e do envelhecimento. A superação da fronteira entre a Inteligência humana e a Inteligência Artificial (IA), a "singularidade", está sendo prevista atualmente para acontecer entre os anos de 2050-2070! E há quem proponha ser esta a verdadeira religião para a qual todas as vidas devem se orientar.

Quanto à origem do termo transumanismo, de acordo com Harrison e Wolyniac (2015) já aparece num artigo do canadense W. D. Lighthall, de $1940 .{ }^{11}$ É sugerido especificamente por Julian Huxley, num artigo de 1951, retomado em obra posterior (1957, p. 13-17) ${ }^{12}$. O artigo de Lighthall lembra o Canto I do Paraíso da Divina Comédia, de Dante Alighieri: Trasumanar significar per verba non si poria [...] (transumanar não pode-se entender por palavra [...] (linha 68-70). A expressão remete a 2 Cor 12,4: “foi arrebatado até o paraíso e ouviu palavras inefáveis, que não é lícito ao homem repetir". Huxley, por sua vez, conclui seu texto intitulado Transhumanism afirmando a crença de que "a espécie humana, se quiser, pode transcender a si mesma [...] em sua totalidade como humanidade." E acrescenta: "Nós precisamos um substantivo para essa nova crença. Talvez transumanismo possa servir: o ser humano permanecendo ser humano, mas transcendendo a si mesmo, realizando novas possibilidades de e para sua natureza humana". Nota-se que a ideia esboçada inclui os elementos que permitirão o uso do termo para diante. Manifesta ainda sua opinião de que a humanidade se encontre no limiar de uma nova forma de existência tão diferente da atual quanto "a nossa difere do homem de Pequim" (p. 17). Em sua avaliação a respeito da história do conceito, Harrison e Wolyniac entendem que o artigo de Lighthall esboça uma "filosofia metafísica progressivista, semelhante, em certo sentido, ao que tanto Julian Huxley quanto Pierre Teilhard de Chardin teriam tentado fazer ao unirem a evolução cósmica, orgânica e cultural" (p. 266). Na opinião de alguns autores, em Teilhard de Chardin é preciso falar em "ultra-humanismo" (DELIO, 2012). Outros autores ainda, falam em meta-humanismo (DERETIĆ; SORGNER, 2016) ou mesmo "neo-humanismo" (HOTTOIS, 2016b, p. 162). O que certamente

\footnotetext{
${ }^{10}$ Bess distingue seis principais áreas em que o termo enhancement se torna escorregadio e controverso: "normal ou funcionamento típico de uma espécie, terapia ou cura, funcionamento natural, autenticidade e a ambiguidade entre 'mais' e 'melhor'”. Em sua conclusão, chama a atenção para a necessidade de se evitarem os extremos ou as posições simplificadas a respeito do que possa ser considerado aumento (augmentation) ou melhora (improvement), dois dos sentidos em que o termo enhancement pode ser usado em Bioética ou que seja "natural" ou "normal", por exemplo (BESS, 2010).

${ }^{11}$ Trata-se de W. D. Lighthall, 'The Law of Cosmic Evolutionary Adaptation: An Interpretation of Recent Thought, Royal Society of Canada, Ottawa. Proceedings and Transactions / Mémoires et Comptes Rendus de la Société Royale Du Canada 1940. ser. 3, v. 34, section 2, p. 135-141. ${ }^{12}$ Estranhamente N. BOSTROM (2011), repete um erro de informação localizando a expressão de J. Huxley numa obra de 1927, onde o termo não ocorre!
} 
distingue o "ultra-humanismo" teilhardiano é o fato de ser uma forma de transumanismo explicitamente relacionado à evolução em direção à plenitude do amor (DELIO, 2012, p. 163).

$\mathrm{Na}$ busca das raízes históricas do significado da ideia de transumanismo N. Bostrom (2011) cita os rituais fúnebres, as tradições religiosas da antiguidade (os poemas de Gilgamesch), os mitos gregos, especialmente o mito de Prometeu, e as tradições orientais.

\subsection{Pós-Humanismo}

O termo geralmente mais conhecido, Pós-Humanismo, de acordo com Tirosh-Samuelson (TIROSH-SAMUELSON, 2012, p. 715-716), possui no mínimo duas vertentes de significado, que podem gerar bastante confusão no debate: o cultural-filosófico e o tecnocientífico. Para desfazer a confusão, sugere notar os aspectos comuns e os distintivos. É comum a ambos o fato de não admitirem "uma essência humana fixa", ou seja, uma natureza humana, sendo esta fundamentalmente uma "obra em progresso": os humanos podem reprojetar a si mesmos a fim de superarem seus limites biológicos. Ambas as tendências saúdam um futuro em que os limites entre humanos, máquinas e animais serão diluídos em favor da ciborguização. $\mathrm{O}$ mais importante: dispensam a reprodução e buscam a destruição dos humanos corporificados resultando numa "eventual obsolência da espécie humana" (p. 715). ${ }^{13}$ É o que uma pesquisa levada a termo por E. Cruz, numa amostra de 68 livros transumanistas, demonstrou. O tema da natalidade é pouco refletido, com a consequência de que o ciclo humano do nascimento e da morte está ausente (CRUZ, 2013, 2015).

Na introdução de sua obra What is Posthumanism? (O que é pós-humanismo?) Cary Wolfe (2010) mostra a complexidade do uso dos termos. Identifica, com Nick Bostrom, por um lado, um sentido literal em que pós-humanismo viria depois do humanismo, no sentido de incluir outros seres para além do humano. Teria como referências a serem consideradas, a natureza e os outros animais. Radicalizaria, além disso, a autonomia humana, continuando o projeto humanista do Iluminismo de "sapere aude!", tenha a ousadia de saber! A tarefa do pós-humanismo consiste, portanto, em completar a desvinculação dos temas e programas humanistas de seus resquícios religiosos e heterônomos. $\mathrm{O}$ autor situa a consolidação do termo em meados dos anos 1990, mas na sua genealogia lembra, por um

\footnotetext{
${ }^{13}$ Levando em conta Luc FERRY (2018, p. XLII), é possível subdistinguir a linha tecnocientífica em terapêutica e "tecnofabricação". A preocupação terapêutica visa apenas melhorar as condições da vida humana, em continuidade com o projeto humanista tradicional - "Pico della Mirandola a Condorcet" - que "defendia a perfectibilidade infinita do ser humano", enquanto a segunda posição leva a uma "ruptura com o humanismo em todos os seus aspectos".
} 
lado, o pensamento de Foucault (2000, p. 536 [edição francesa, 1966]) ${ }^{14}$ e, por outro, as conferências sobre cibernética, patrocinadas pela fundação Macy, entre 1946-1953 (Cybernetics: The Macy Conferences 1946-1953). Essas conferências reuniam as maiores autoridades do mundo para discutirem as implicações das ciências emergentes, deixando clara a aproximação entre máquina e seres humanos. Stefan Herbrechter, por sua vez, acrescenta a esses marcos uma ocorrência do termo pós-humano já em 1656, registrado pelo Oxford English Dictionary e um outro uso documentado e comentado pelo teosofista H. P. Blavatsky, em 1888 (Cf. HERBRECHTER, 2013, p. 33). O primeiro uso crítico do termo se encontra em Ihab Hassan (1977) num texto sobre o estado do debate a respeito do pós-humanismo naquele momento. Merece destaque especial o fato de Ihab Hassan usar o recurso literário da controvérsia ao estilo medieval, com diferentes personagens numa encenação sob o título de Prometeu como intérprete (Prometheus as Performer). Essa coincidência entre o uso do mito de Prometeu, já referida nas explicações de N. Bostrom sobre o transumanismo, acima, com o termo pós-humanismo pode ser facilmente associada também a Nietzsche e ao super-homem. Traz embutida a ideia de uma espécie de apoderamento do divino.

Pós-humanismo e transumanismo podem, por conseguinte ser considerados dois momentos distintos da realidade humana em transição. Enquanto transumanismo diz respeito à passagem ou ao movimento de passagem, o "pós-humano" representa a ideia de estágio ao qual se chega. O resultado do transumanismo seria o pós-humano, com o surgimento de um ser para além do atual homo sapiens sapiens, uma integração perfeita entre máquina, inteligência artificial e ser humano atual (TIROSH-SAMUELSON, 2018, p. 13-17). Herbrechter (2013, p. 31-74) ao falar da "genealogia do pós-humanismo", afirma que o pós-humanismo é uma resposta à demanda de Nietzsche por uma "moral crítica" em sua obra Genealogia da Moral (NIETZSCHE, 2007, Prefácio § 6; 2 ${ }^{a}$ dissertação, § 24). Bainbridge, no entanto, estende a análise a várias obras do mesmo pensador a fim de prevenir uma aplicação e extensão impensada do transumanismo (BAINBRIDGE, 2010) com Nietzsche.

Tirosh-Samuelson entende que há uma oposição entre a forma como o pós-humanismo de corte mais científico e tecnológico se relaciona com o Iluminismo e a forma como a vertente cultural-filosófica se relaciona. Enquanto para a tendência tecnológica o pós-humanismo seria uma conti-

\footnotetext{
${ }^{14}$ Wolfe se refere ao final de As palavras e as coisas: "Se estas disposições viessem a desaparecer tal como apareceram, se, por algum acontecimento de que podemos quando muito pressentir a possibilidade, mas de que no momento não conhecemos ainda nem a forma nem a promessa, se desvanecessem, como aconteceu, na curva do século XVIII, com o solo do pensamento clássico - então se pode apostar que o homem se desvaneceria, como, na orla do mar, um rosto de areia".
} 
nuidade e intensificação do iluminismo e da razão humana, para a vertente filosófica se trataria antes de uma crítica ao iluminismo por sua metafísica e as consequências prejudiciais para a humanidade. Anota ainda a Autora uma diferença em relação às concepções religiosas. Enquanto a tendência filosófica se inclina ao secularismo, a vertente científica e técnica se apresenta com pretensões de transcendência através da ciência e tecnologia. O transumanismo, por sua vez, pode ser entendido como o processo de passagem ao pós-humanismo, com, a menos duas tendências distintivas: "Uma, focada na melhora [enhancement] humana no presente e a outra centrada na ciber-imortalidade no futuro" (TIROSH-SAMUELSON, 2012, p. 716). Nestas circunstâncias, como sugere Bishop (2010, p. 703), em vez de pós- e transumanismo no singular, talvez fosse melhor falar em pós- e transumanismos, no plural.

Do que precede, é possível assumir como válida a distinção entre Trans- e Pós-Humanismo como expressando, o primeiro, a dimensão processual, e o segundo, a dimensão finalista ou teleológica, uma espécie de horizonte direcional. Não se trata, portanto, sem mais de simples momentos cronológicos: o Pós-Humanismo seria a realização definitiva do que se teria buscado através do Transumanismo. Em certo sentido, cada concretização do movimento transumanista - uma terapia genética, por exemplo - pode ser uma antecipação do Pós-Humano. Por outro lado, a eventual "singularidade", ou a extensão da vida por décadas ou séculos, como condição realizada do Pós-Humanismo, sempre ainda implicaria em futuro aberto, portanto, Transumanismo.

Como uma primeira conclusão da elucidação conceitual e das concepções trans- e pós-humanistas, é possível afirmar que a busca humana por uma superação de seus limites hoje conta com recursos para mais recursos, mas se encontra igualmente ante o desafio de responder pelo que faz. Abre para si um futuro sem fim, mas ao mesmo tempo se arrisca a uma armadilha sem volta. Não por nada os principais pregadores da H+ (Humanity Plus), insistem nos seus propósitos de uma universalização dos bens gerados como uma forma de garantir uma certa forma de sobrevivência. Um candidato a governador da Califórnia - o estado do Silicon Valley - o ícone e sede de várias das iniciativas transumanistas em vista do pós-humanismo, prometeu nada menos do que um salário base de $\$ 5000,00$, assistência universal de saúde e, no futuro, a eliminação da morte!

\section{Trans-e pós-humanismo e natureza humana}

As ciências modernas como a Antropologia Cultural, a Psicologia, bem como a Psicanálise e Psiquiatria, a Teoria da Evolução e a Neurociência, ao lado de várias correntes filosóficas, mostraram que uma simples afirmação 
estática de um conceito de natureza humana dificilmente se sustenta. É, portanto, com razão que $\mathrm{H}$. Tirosh-Samuelson se refere ao debate havido nas últimas seis décadas sobre a natureza humana: "Testemunhamos o repensamento e o debate do sentido de ser humano, levados pela aceleração dos avanços científicos e inovações tecnológicas" (TIROSH-SAMUELSON, 2012, p. 712). Com toda razão Jonathan Jong reclama o empenho da Teologia e das Ciências Humanas, em diálogo com as ciências, a Biologia em particular, na elaboração de conceitos que possam dar conta dos desafios levantados pela Biotecnologia (JONG, 2018, p. 350). Um conceito ainda mais difícil é o de pessoa (humana). Quando, portanto, se fala em pós- ou transumanismo, de que humanismo e de que humano se está falando? Quem e o que é o ser humano?

Karl Rahner aborda o tema da "natureza humana" ao escrever sobre automanipulação e manipulação genética e "Experimento Ser Humano" (Experiment Mensch) e "O problema da manipulação genética" (Zum Problem der genetischen Manipulation) textos publicados respectivamente em 1965 e 1967(In: RAHNER, 2002, p. 437-455; 498-524). O primeiro artigo, sobre a automanipulação, inicia por constatar que "hoje o ser humano muda $a$ si" (p. 438). E este mudar a si corresponde, na opinião de Rahner, à Antropologia cristã para quem o ser humano é a natureza automanipuladora, "pois para uma autocompreensão cristã o ser humano, como ser de liberdade é aquele que da maneira mais radical dispõe sobre si mesmo". A realização dessa radicalidade faz com que sua existência tenha início "como essência radicalmente aberta, inacabada que se termina apenas como aquilo que ela mesma se fez" (p. 444). Em outras palavras, Rahner descreve aqui a possibilidade principal de o ser humano também se mudar em razão de sua constituição originária de ser que se faz e não simplesmente se entende como uma "coisa" já previamente dada. Seria interpretar o pensamento de Rahner também em termos "existência" humana, ao invés de falar simplesmente em "natureza" humana.

De modo semelhante, ao falar explicitamente da manipulação genética afirma ser inviável negar a manipulação a priori para deixá-la apenas à natureza, pois "para uma compreensão cristã [...] o ser humano não é simplesmente o produto da 'natureza' [...]. Ele é muito mais o ser que [...] 'faz' de si mesmo aquilo que e quem quer ser e definitivamente será". O que muda com o avanço das ciências é o fato de hoje o ser humano "poder manipular-se em sua tangibilidade social e corporal" de forma planejada e racional (p. 500-501). Embora Rahner aqui se posicione claramente contra a manipulação genética, a fundamentação está baseada num conceito dinâmico, existencial, de "natureza" humana. A pergunta levantada por K. Rahner a respeito da manipulação evidentemente se dá num contexto em que o transumanismo ainda não tinha nenhuma expressão. No entanto, suas abordagens sobre a natureza humana permitem conexões significativas com as perguntas relativas. Sob o pano de fundo de sua Antropologia Teológica 
geral em que o ser humano é entendido como a existência radicalmente aberta - ouvinte da Palavra - orientada para o mistério divino, como um existencial sobrenatural e autotranscendência, permitindo o advento da presença gratuita do mistério como autocomunicação divina, o ser humano é constitutivamente pessoa relacional e criativa.

No conjunto do pensamento de Rahner, em coerência com a tradição cristã, o ser humano se constitui na condição de possibilidade da encarnação da Palavra, e, portanto, da unidade insuperável entre o divino e humano em Jesus de Nazaré, o Cristo. Contudo, essa abertura está marcada pela contingência, vulnerabilidade e pelo risco do pecado. Um projeto de ser humano, do ponto de vista teológico cristão, na expressão de James M. Childs, Jr. "é sempre realista e esperançoso". Realista porque lembra da sua condição de ser dependente, de ser capaz de destruir seu semelhante, mas também de aceitar entrar numa história de graça e salvação em cujo horizonte está a definitiva comunhão com a Transcendência pela encarnação, morte e ressurreição de Jesus de Nazaré.

Em sentido semelhante, podem ser aduzidas as reflexões de Johannes Grössl em sua avaliação teológica do transumanismo. Inicia por afirmar que "o ser humano foi criado por Deus a fim de poder entrar em relação com seu criador e suas concriaturas" (In: GÖCKE; MEIER-HAMIDI, 2018, p. 339-361, aqui p. 340). Em outras palavras, a relação com a transcendência, com o outro de si, constitui o núcleo existencial e irradiador de um si e ao mesmo tempo o espaço e a polaridade a partir da qual se dá a chance até mesmo de um mais para além da contingência estreita do "mim" aqui e agora.

Um tema particular da Antropologia Filosófica e Teológica é a constituição psicossomática do ser humano. Se por um lado, existem posições defendendo um monismo materialista, constatam-se também concepções abertas a dimensões não reducionistas. Estranhamente, como notam alguns autores, no transumanismo radical, orientado ao pós-humanismo, há o que se pode chamar, uma concepção dualista radical, em que o corpo seria apenas uma espécie de "hardware" ao qual estaria vinculada a personalidade, subjetividade, eu, ou inteligência, entendendo ser possível migrar uma personalidade inteira de um "hardware" a outro. Esse outro, poderia ser tanto um corpo biológico, no sentido tradicional do termo, quanto um equipamento-máquina (robô, p. ex.). Ainda que na história do cristianismo possam existir posições favoráveis a um dualismo radical, em que espírito e matéria estejam apenas exteriormente vinculados, a posição mais predominante, ao menos em algumas confissões, como o catolicismo, é de um dualismo mitigado, sempre pensado como unidade essencial. A confissão da ressurreição dos mortos ou da "carne" é parte integrante das afirmações essenciais da fé cristã. James Keenan usa esse argumento ao falar do corpo como incorporação e relacionalidade na tradição católica 
- Embodiment and Relationality (In: MERCER; MAHER, 2014, p. 156-171, aqui, 158). Numa primeira conclusão de seu trabalho afirma taxativamente que "onde os transumanistas deixam para trás o corpo humano, também abandonam todas as pessoas cristãs" (MERCER; MAHER, 2014, p. 162).

A posição filosófica de um dualismo mais radical tem como nome representativo na Modernidade a figura de René Descartes. Para esse pensador, a res extensa, a materialidade humana se destaca da res cogitans, a substância pensante, e portanto espiritual. Embora sejam discutíveis as simplificações do seu pensamento, não resta dúvida que pode estar na raiz de concepções dualistas antagônicas posteriores em que ora se exclui a dimensão espiritual, na forma de um materialismo reducionista, ora considera-se a dimensão corporal descartável em favor de espiritualismos alienantes ou gnósticos. Para além dessa divisão, a recuperação de uma tradição filosófica de cunho mais judaico, assim como a Filosofia Existencialista, permitiu estabelecer as bases para a reconstrução de uma concepção unitária do ser humano como unidade psicossomática "monista". Tanto no âmbito da Teoria da Evolução quanto das Neurociências fala-se em Monismo ou Naturalismo não materialista ou não reducionista. ${ }^{15}$

O fato de se propor uma unidade psicossomática para a condição humana ainda não significa, e não precisa significar, a sua plena realização atual. Pensando em termos escatológicos, é na ressurreição dos mortos (da carne) que acontece a plena unidade. Trata-se, portanto, de uma unidade a ser historiada e realizada do tempo em direção à definitividade. No tempo e na história, seguindo a sugestão de J. Keenan, pode afirmar-se que a unidade corpo e alma, não está dada, "mas é uma tarefa" uma integração "entre corpo e mente, corpo e alma". A condição de ser humano é "trabalhar e laborar para a integração da mente e do corpo; ser humano é buscar ser um" ${ }^{16}$ Em certo sentido é possível entender essa "tarefa" como experiência essencial de uma dialética mediadora em que a dimensão espiritual, a dimensão do si, na relação de sua corporeidade historiadora, constrói o eu, como ponto de partida, polaridade, para o encontro com outro de si, o outro eu. Pode pensar-se essa construção também com a dialética paulina do "não faço o bem que quero, mas pratico o mal que não quero" (Rm 7,19), ou do Espírito e da carne (Gal 5,17).

\footnotetext{
${ }^{15}$ Cf. a respeito, p. ex., MURPHY, Nancey. Supervenience and the Downward Efficacy of the Menta: a Nonreductive Physicalist Account of Human Action (In RUSSELL et al., 2000, p. 147-164) Para a relação com a Teoria da Evolução, pode ver-se da Autora, Bodies and Soul, or Spirited Bodies? (MURPHY, 2006, p. 39-70; MURPHY; STOEGER, 2007). John Haugth aborda o tema na sua obra geral sobre Cristianismo e Ciência (HAUGHT, 2010, p. 189-214). ${ }^{16}$ KEENAN, James F. Embodiment and Relationality: Roman Catholic Concerns about Transhumanist Proposals (In: MERCER, C.; MAHER, D. (Orgs.), p. 156-171, aqui, p. 156). Para a questão da corporeidade no pós-humanismo entre encarnação e ressurreição cf. também o artigo de Oscar Chemello (CHEMELLO, 2011).
} 
Em conclusão a esse momento segundo, é possível sublinhar a estrutura essencial de ser humano como um ser que se ultrapassa por definição. A condição de possibilidade do transumanismo em direção ao pós-humanismo é a própria realidade mais profunda do ser humano. Neste sentido, falar em pós-humano só pode ser entendido como parte do projeto do humano. É o humano estendido para além de si mesmo que retorna sempre a si para levar além de si. Na condição realista de sua existência está marcado por sua finitude. Mas é exatamente a finitude que possibilita sua existência, que do contrário se diluiria e subsumiria. Na finitude que faz fronteira com outras finitudes será possível acolher essas outras e construir o "nós", o "eu-em-nós", na expressão de Axel Honneth (2010, p. 261-279)17. Na acolhida de si mesmo em sua condição de se transcender, e na acolhida de toda alteridade, seja seu semelhante, seja o outro ser vivo, ou a natureza, ou o Mistério Divino, se constrói e constrói outros; na negação dessa sua condição, ou de outrem, destrói a si mesmo e se torna uma polaridade letal que distende aniquiladoramente para a totalidade.

\section{O agir humano e o trans- e pós-humanismo - aproximações éticas}

Para as questões éticas do transumanismo e do pós-humanismo, é necessário levar em conta ao menos os aspectos antropológico-filosóficos, teológicos, econômicos e sociais. Evidentemente seria muito extenso abordar satisfatoriamente a cada aspecto. ${ }^{18}$ Tanto os aspectos históricos e conceituais, quanto as indicações a respeito da relação com a natureza humana já permitiram vislumbrar questionamentos práticos relevantes. É legítimo buscar o transumanismo e o pós-humanismo, levando em conta seu impacto sobre a condição humana? Quem é este ser humano, do ponto de vista da fé e da Teologia? É possível e correto falar em ética na ciência? Quem será a instância reguladora e executora das normas? Como serão distribuídos os ônus e bônus dos avanços?

Uma observação inicial, que a concepção evolucionista do Transumanismo e do Pós-humanismo parece deixar à parte, diz respeito à confusão entre evolução e progressividade. Biologicamente falando, evolução é qualquer transformação no mundo da vida, independentemente do fato de ser num sentido progressivo ou num sentido "regressivo". O diferente não

\footnotetext{
${ }^{17}$ Axel Honneth está falando do "eu-em-nós como força motora de grupos" e conclui dizendo que o "eu procura o nós da vida comum de grupo, porque também depois da maturação ainda é dependente do reconhecimento social" (p. 279).

${ }_{18}$ Talvez a maior incidência entre Ética e trans- e pós-humanismo se dê na Bioética, justamente por a saúde ser um dos temas mais abordados.
} 
necessariamente é o melhor ou mais perfeito. A aparição do ser humano na cadeia evolutiva não foi o único resultado da evolução, mas apenas um deles, um dos ramos da árvore da vida. Com essa observação em mente, pode pensar-se uma evolução da espécie humana, em resposta que responda a determinadas situações da realidade, do ambiente ou da influência de intervenções, mas que não necessariamente seria por um "mais" ou um "melhor", mas poderia ser um "menos" ou um "pior"! Com isso, um postulado inicial que o trans- e pós-humanismo se propõe deve ser questionado. Querer acelerar a evolução, no sentido de tornar o ser humano do futuro uma nova espécie, não significa evolução biológica e sim o desenho - projeto - de um outro ser, de outra espécie. É inerente à mudança no ser vivo a possibilidade de ser diferente, sem que seja $\mathrm{H}+$.

O pressuposto teológico de uma consciência ética teológica no contexto do trans- e pós-humano, é a consciência da criaturalidade. A pretensão a ser deuses (HARARI, 2017) colapsa diante da simples evidência de que se transformaria inevitavelmente numa luta de deuses, ou de Prometeuses. Mesmo que o discurso trans- e pós-humanista se afirme por vezes como uma superação da utopia, em forma de nova narrativa, deixa entrever aspectos éticos seculares, não religiosos, como já se assinalou anteriormente. Pelo contrário a consciência da criaturalidade abre à condição de imagem do divino pela qual é possível pensar a relação com o trans- e pós-humanismo. Ted Peters reflete exatamente esse princípio, para concluir que Deus chama a cada um e todas as pessoas para um objetivo assinalado "nossa verdadeira humanidade na participação com a criação redimida". Nessa condição destaca a capacidade cocriadora com Deus como um sinal, "uma oportunidade proléptica que abre o espírito humano para buscar a transformação", na qual se antecipa o futuro. "Esse impulso antecipador", escreve ele, "posto no interior da criaturalidade humana torna-se o fundamento da ética, o ponto de partida para buscar o futuro que é melhor do que o passado (PETERS, 2018, p. 360).

Nos artigos já mencionados de Karl Rahner, é possível identificar alguns critérios úteis a serem levados em conta na avaliação ética. Antes de mais nada, a condição humana a ser aceita em liberdade como uma espécie de "existencial" e a tarefa correspondente da liberdade precisam também ser perceptíveis no espaço e no tempo. Desse modo, a liberdade pessoal é também a liberdade da outra pessoa e é mutuamente constitutiva. Ora, a manipulação genética - pode dizer-se também transumanizadora - potencialmente rompe a liberdade de outrem, na medida em que pode condicionar essa mesma liberdade no próprio sujeito ou nos demais sujeitos.

Além do aspecto transcendental, Rahner aponta ainda para os riscos da manipulação estatal, poderia dizer-se também de grupos econômicos ou poderes. Na medida em que boa parte da pesquisa em vista da melhoria/ aumento está nas mãos de grandes grupos econômicos ou dos laboratórios 
militares, o risco de abuso, como os fatos comprovam, é real. Espionagem em larga escala, manipulação da população por desinformação customizada, "pos-verdade", invasão da privacidade, fabricação e uso de armas "inteligentes" e robôs-matadores, sem contar a indústria de alimentos, são todos fatos que mostram a ambiguidade dos projetos trans- e pós-humanistas. Com Sandra A. Ham é justo lembrar que "o avanço da ciência e da tecnologia é como uma espada de dois gumes" com benefícios materiais e com problemas, com materialismo e meios para novos egoísmos sem consideração em relação aos outros (HAM, 2016, p. 203). Também Ted Peters chama a atenção para a possibilidade de o transumanismo ser ingênuo quando adota uma Antropologia que ignora "a tendência a converter o que é bom em algo mau" (PETERS, 2015, p. 147).

Um terceiro aspecto lembrado por Rahner, para o qual também outros autores apontam, é a diferença entre o que é técnica ou cientificamente factível e sua eticidade: nem tudo o que se pode tecnicamente, é também eticamente justificável. E do ponto de vista realístico, "há coisas que não podem primeiro ser feitas para depois, com mais experiência, serem corrigidas para se fazer melhor", como seria o caso de uma eventual guerra atômica. Há ações cujos efeitos são irreversíveis (p. 510-524). Especialmente a essa última observação de Rahner poderia aduzir-se o princípio responsabilidade. ${ }^{19}$

A partir dessa condição fundamental do ser humano frente à possibilidade de sua própria manipulação e da sua interação com a natureza, esboçada por K. Rahner, podem inferir-se algumas reflexões éticas cristãs frente ao pós - e transumanismo em sua situação atual, aliás, muito distinta da dos anos 1960, quando surgiram os textos de Rahner. É desejável que essa reflexão ética cristã se estende à existência humana inteira: a autocompreensão do ser humano, sua relação consigo, isto é sua "natureza", sua relação com os outros seres humanos, em sua condição de pessoas, a relação com o ambiente ou natureza e a relação com a transcendência como filho e imagem do Mistério Divino.

Já foi tocado o tema da "natureza" humana. Aqui é preciso apenas sublinhar, com P. Göcke e outros, que do ponto de vista das ciências naturais o conceito de humano diz respeito a uma determinada espécie de ser vivo, o homo sapiens sapiens, enquanto para Filosofia e Teologia, geralmente o ser humano remete a uma concepção metafísica. Define-se em sua liberdade, relacionalidade e condição de ser pessoa, por exemplo, (Göcke, Designobjekt Mensch?! In: GÖCKE; MEIER-HAMIDI, 2018, p. 120-121). O transumanismo geralmente considera apenas o aspecto biológico, embora,

${ }^{19}$ Como seria de imaginar, existem vários estudos que recorrem a Hans Jonas. Talvez um dos mais destacados seja o de Tirosh-Samuelson (2007). 
seu horizonte possa incluir questões metafísicas, na medida em que está apoiado numa concepção de ser humano manipulável em sua liberdade, responsabilidade e relacionalidade. Além disso, segundo o mesmo autor, é possível distinguir entre as alterações transitórias e as permanentes, entre opcionais possíveis e impostas. Distingue, em consequência, entre transumanismo radical e moderado. Pode falar-se em transumanismo moderado quando as alterações, melhorias ou aumentos, são de ordem quantitativa ou qualitativa, sem alterarem a pertença à espécie biológica. Um implante ou prótese ou mudança no código genético para recuperar ou corrigir uma perda ou falta. Diferente, seria a intervenção qualitativa que muda a relação com a condição atual da espécie. Dotar o ser humano de capacidade para ser subaquático.

Do ponto de vista das transformações possíveis, pode argumentar-se em favor da intervenção para a melhora e a transformação a partir do fato, lembrado por Jonathan Jong de que o ser humano ao longo da história, e especialmente nos últimos séculos se desenvolveu em vários aspectos de sua existência: longevidade, forma do corpo, desempenho intelectual, dentre outros (JONG, 2018, p. 345). De modo semelhante, pode concordar-se com Keenan ao registrar as práticas "bem financiadas que nos podem levar a uma equidade maior ou a uma dominação maior. Para apreciar seu valor ético, é necessário perguntar sobre quais melhoras / aumentos, com que objetivos, com que custos e financiados por quem?" (p. 167). Além disso, precisa considerar os efeitos cósmicos traduzidos na expressão Antropoceno tema, aliás, tratado por Andre Banning numa seção do livro Designobjekt Mensch (Das Anthropozän die Menschheit als geologischer Faktor? In: GÖCKE; MEIER-HAMIDI, 2018, p. 409-426).

Contudo, essas transformações precisam justificar-se diante de critérios mais gerais da sociedade. Aqui, do ponto de vista, da Teologia da Libertação, e da opção eclesial pelos pobres, ou da Ecoteologia, os benefícios de uns precisam ser os benefícios de todos, a começar pelos mais pobres; o bem-estar humano precisa estar em sintonia com a saúde e sustentabilidade do ambiente em que vivem todas as pessoas e viverão as gerações futuras.

Para concluir essa leitura da relação entre ética cristã e trans- e pós-humanismo, sublinhe-se mais uma vez o discurso ético presente em várias manifestações dos próprios protagonistas, uma preocupação de intelectuais mesmo não vinculados religiosamente, e iniciativas como a do abaixo-assinado contra a fabricação e uso dos robôs matadores com Stephen Hawking à frente, assim como a discussão no contexto da guerra justa, no artigo de Christopher J. Finlay (FINLAY, 2018), sendo que o número inteiro desse periódico está dedicado às questões de uma dissuasão (deterrence) do recurso às ciberarmas. 


\section{Conclusão}

"Assim, também a inteligência artificial, a robótica e outras inovações tecnológicas devem ser empregadas de modo que contribuam para o serviço da humanidade e para a proteção da nossa casa comum e não o exato contrário, como infelizmente algumas estimativas preveem" (Papa Francisco em sua mensagem ao Forum Econômico Mundial, 2018).

Uma avaliação ética do trans- e pós-humanismo deve estar baseada na consciência de sua ambiguidade como qualquer atividade humana. Uma simples reedição nietzscheana da pretensão prometeica de ser deuses parece não estar explícita em boa parte dos trans- e pós-humanistas. Os textos referidos ao longo do artigo, são uma pequena amostra dos debates e das contribuições já disponíveis em ambiente de Teologia. Ainda que não se fizesse a menção explícita, alguns dos autore(a)s se reconhecem como "transumanistas" cristãos. Algumas das obras citadas estudam especificamente a relação entre trans- e pós-humanismo com religiões, inclusive confissões cristãs, dentre as quais o catolicismo. Não por acaso, o próprio Papa Francisco em sua mensagem à edição 2018 do Fórum Econômico Mundial, apelou para o emprego adequado de tecnologias que estão associadas aos projetos trans- e pós-humanistas. Devem estar a serviço de todos e da "casa comum".

As tecnologias, vistas em si mesmas, como capacidade humana para manipular ou mudar condições de existência, gozam de uma neutralidade relativa. A neutralidade é relativa porque a simples aquisição de tecnologia, ou mesmo a ciência pode estar viciada. Quem financia a pesquisa? Donde provém os recursos? Com que finalidade? Quem são os sujeitos envolvidos? Como são assegurados seus direitos e sua integridade? A quem se destinam os eventuais resultados? São algumas questões a serem postas também aos trans- e pós-humanistas. A sua aplicação dos resultados pode ser problemática na medida em que interfere em valores afirmados: integridade do ser humano e o princípio do considerado "natural". Sob uma outra perspectiva ainda pode representar um problema se for levado em conta o fato de consumir muitos recursos e servir apenas a poucas pessoas.

Deixando em aberto uma definição muito estrita e fixista do que seja humano, será preciso continuar a construção de um conceito aberto, mas reconhecível. Aqui a teoria do reconhecimento é fundamental, já que só mediante o reconhecimento alguém pode ser entendido como sujeito e membro de uma sociedade de iguais e semelhantes.

Enquanto o transumanismo se preocupa em aperfeiçoar a condição humana e melhorar o seu desempenho, de forma acessível e universalizável, sem retirar as chances de existência e vida de outros seres humanos, deve ser considerado um esforço positivo. De maneira semelhante, o desenvol- 
vimento de habilidades coincidentes com habilidades humanas, mesmo intelectuais e mentais, para máquinas ou outras entidades não humanas, em si mesmo pode ser moralmente aceitável, desde que não implique em destruição dos próprios humanos.

Muito distinta será a situação quando interferir diretamente nos organismos das pessoas, ou quando representar manipulação do ser humano. Aqui se trata de levar o ser humano atual para uma condição posterior a si mesmo, entendendo-se como um passo adiante na evolução. Em outros termos, o que se propõe é a compreensão de evolução como realidade linear de complexificação e aperfeiçoamento. Contudo, é sabido que a evolução não é um processo linear do simples ao complexo e do imperfeito ao mais perfeito. É antes uma condição da vida que se afirma distintamente frente ao ambiente circundante ao qual se adapta ou não. Implicada está a discussão a respeito do finalismo do processo evolutivo, em geral não aceito nas Ciências da vida. Ora, se não é possível reconhecer cientificamente uma finalidade que permitiria reconhecer a passagem do simples ao complexo como uma lei interna da natureza, não há razão para entender as mudanças na relação ser humano e máquina como uma progressão evolutiva. Pode ser evolução, mas nem por isso é progresso. Poderia ser entendido simplesmente como transformação e que pode ser para pior e precário.

O que se pode dizer a respeito da fé? É possível identificar três correntes transumanistas: indiferentes, ateus e religiosos. A corrente transumanista indiferente não se posiciona expressamente a respeito de assuntos religiosos, enquanto a posição religiosa pode, por um lado, pretender reconhecer no transumanismo um apoio para concepções religiosas, como por exemplo, para a ideia criadora e divinizadora do ser humano, ou, por outro, identificar-se como sendo uma forma de religião. $\mathrm{O}$ transumanismo ateu se apresenta como a sobreposição ao religioso que seria uma realidade obsoleta.

Discutir o trans- e pós-humanismo do ponto de vista da Teologia, exige, portanto, levar em conta as diferentes concepções filosófico-teológicas implicadas. Na hipótese de se estar diante de um procedimento científico sem concepções religiosas explícitas, será necessário buscar os critérios éticos pertinentes. Quando se trata de pesquisas no campo da inteligência artificial, por exemplo, sem envolver diretamente seres humanos, a primeira questão teológica é de ordem ética social. Os recursos investidos oneram as vidas das pessoas mais vulneráveis? Os produtos a serem desenvolvidos impactam negativa ou positivamente o acesso ao trabalho, à economia da população? Gera desemprego? A quem servirão os ganhos econômicos derivados do uso e dos recursos das máquinas?

A tarefa da Teologia consiste, ademais, em auxiliar tanto a religião e as religiões no discernimento das funções terapêuticas e substitutivas da tec- 
nociência. A forma de participação, no entanto, se dará não pela afirmação de critérios estabelecidos ou pretensamente recebidos a priori e sim num processo criativo - no sentido da Findung alemã - de elaboração e construção hermenêutica, pois essa é uma das características do discernimento. As funções terapêuticas parecem mais fáceis de serem admitidas do que as substitutivas. Contudo, no estágio atual do conhecimento, as terapias com intervenção direta no genoma e no DNA humanos, por se moverem no âmbito de consequências imprevisíveis e incalculáveis, sequer têm aprovação irrestrita da comunidade científica.

O que nesse momento teologicamente precisa também ser lembrado, são os eventuais efeitos genocidas associados ao transumanismo. O elevado custo, direto ou indireto, de vidas e da condição humana para a realização das pesquisas e aplicações. $\mathrm{O}$ dinheiro e os recursos arrecadados para financiar os projetos, representa uma forma de concentração de bens nas mãos de poucas instituições e pessoas determinando a morte real de famintos e migrantes e uma seleção indireta de indivíduos (pessoas?) aptos ao prolongamento da vida ou à pretensão da imortalidade.

\section{Referências}

BAINBRIDGE, W. Burglarizing Nietzsche's Tomb. Journal of Evolution and Technology, Hartford, v. 21, n. 1, p. 37-54, 2010.

BESS, M. Enhanced Humans versus "Normal People": Elusive Definitions. Journal of Medicine and Philosophy, Oxford v. 35, n. 6, p. 641-655, 1 dez. 2010. Disponível em: <https:// academic.oup.com/jmp/article-lookup/doi/10.1093/jmp/jhq053>. Acesso em: 1 ago. 2018.

BISHOP, J. P. Transhumanism, Metaphysics, and the Posthuman God. Journal of Medicine and Philosophy, v. 35, n. 6, p. 700-720, 1 dez. 2010. Disponível em: <https:// academic.oup.com/jmp/article-lookup/doi/10.1093/jmp/jhq047>. Acesso em: 30 set. 2018.

BOSTROM, N. PHILOSOPHY DOCUMENTATION CENTER. Transhumanist Values. Journal of Philosophical Research, Charlottesville v. 30, n. 9999, p. 3-14, 2005. Disponível em: <http://www.pdcnet.org/oom/service?url_ver=Z39.88-2004\&rft_val_fmt=\&rft. imuse_id=jpr_2005_0030Supplement_0003_0014\&svc_id=info:www.pdcnet.org/collection>. Acesso em: 22 set. 2018.

A History of Transhumanist Thought. p. 30, 2011. Disponível em: <https:// nickbostrom.com/papers/history.pdf>. Acesso em: 15 set. 2018.

. Superinteligência: caminhos, perigos, estratégias. [S.1.]: Darkside Books, 2018.

CHEMELLO, O. R. Antropologia pós-humana: diálogos entre Teologia e tecnologia. Teocomunicação, Rio Grande do Sul, v. 41, n. 2, p. 253-273, 2011.

CRUZ, E. R. Transhumanism and the Fate of Natality. Introduction. Zygon $®$, Cicago v. 48, n. 4, p. 916-935, dez. 2013. Disponível em: <http://doi.wiley.com/10.1111/ zygo.12044>. Acesso em: 22 set. 2018. 
. The Evolution of Human Birth and Transhumanist Proposals of Enhancement. Zygon®, v. 50, n. 4, p. 830-853, dez. 2015. Disponível em: <http://doi.wiley. com/10.1111/zygo.12217>. Acesso em: 15 out. 2018.

DELIO, I. Transhumanism or Ultrahumanism? Teilhard de Chardin on Technology, Religion and Evolution. Theology and Science, Berkeley, v. 10, n. 2, p. 153-166, maio 2012. Disponível em: <http://www.tandfonline.com/doi/abs/10.1080/14746700.2012. 669948>. Acesso em: 22 set. 2018.

DERETIĆ, I.; SORGNER, S. L. (Org.). From humanism to meta-, post-, and transhumanism? Frankfurt am Main: Peter Lang Edition, 2016.

FERRY, L. A revolução transumanista. Barueri: Manole, 2018.

FINLAY, C. J. Just War, Cyber War, and the Concept of Violence. Philosophy $\mathcal{E}$ Technology, Dordrecht v. 31, n. 3, p. 357-377, set. 2018. Disponível em: <http://link. springer.com/10.1007/s13347-017-0299-6>. Acesso em: 24 set. 2018.

FOUCAULT, M. As palavras e as coisas: uma arqueologia das ciências humanas. 8. ed. São Paulo: Martins Fontes, 2000.

FRANCISCO, Papa. Mensagem do Papa Francisco ao Presidente Executivo do Fórum Econômico Mundial de Davos (Suíça). Disponível em: <http://w2.vatican.va/content/ francesco/pt/messages/pont-messages/2018/documents/papa-francesco_20180112_ messaggio-davos2018.pdf>. Acesso: 19/set/2018.

FUKUYAMA, F. Nosso Futuro Pós-Humano: consequências da revolução da biotecnologia. Rio de Janeiro: Rocco, 2003.

GÖCKE, B. P.; MEIER-HAMIDI, F. (Org.). Designobjekt Mensch: Die Agenda des Transhumanismus auf dem Prüfstand. Freiburg: Herder Verlag, 2018. Acesso em: 30 set. 2018.

GREEN, B. P. Transhumanism and Roman Catholicism: Imagined and Real Tensions. Theology and Science, Berkeley, v. 13, n. 2, p. 187-201, 3 abr. 2015. Disponível em: <http://www.tandfonline.com/doi/full/10.1080/14746700.2015.1023528>. Acesso em: 24 set. 2018.

HABERMAS, J. O futuro da natureza humana: a caminho de uma eugenia liberal? São Paulo: Martins Fontes, 2004.

HAM, S. A. Spirituality in Christian Transhumanism: Commentary on Cole-Turner, Green, and Cannon. Theology and Science, Berkeley, v. 14, n. 2, p. 202-217, 2 abr. 2016. Disponível em: <http://www.tandfonline.com/doi/full/10.1080/14746700.2016. 1156331>. Acesso em: 22 set. 2018.

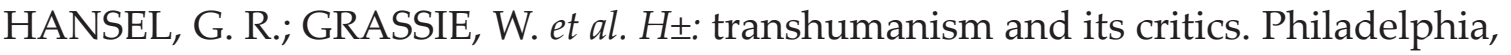
PA: Metanexus Institute, 2011.

HARARI, Y. N. Wir werden Götter sein“. Spiegel-Gespräch mit dem israelischen Historiker Yuval Noah Harari. Der Spiegel, 2017, p. 104-107. Acesso em: 25 ago. 2018.

HARAWAY, D. J. Manifestly Haraway. [S.1: s.n.], 2017. Disponível em: <http://dx.doi. org/10.5749/minnesota/9780816650477.001.0001>. Acesso em: 6 set. 2018.

HARRISON, P.; WOLYNIAK, J. The History of "Transhumanism". Notes and Queries, Oxford, v. 62, 1 set. 2015. Disponível em: <https://www.researchgate.net/ publication/281298815_The_History_of_'Transhumanism'>. Acesso em: 20 set. 2018. 
HASSAN, I. Prometheus as Performer: Toward a Posthumanist Culture? The Georgia Review, Atenas v. 31, n. 4, p. 830-850, 1977. Disponível em: <http://www.jstor.org/ stable/41397536>.

HAUGHT, J. F. Cristianismo e ciência: para uma teologia da natureza. São Paulo: Paulinas, 2010.

HERBRECHTER, S. Posthumanism a critical analysis. London: Bloomsbury, 2013.

HONNETH, A. Das Ich im Wir: Studien zur Anerkennungstheorie. Berlin: Suhrkamp, 2010.

HOTTOIS, Gilbert. ¿El transhumanismo es un humanismo? Bogotá: Universidad E1 Bosque, 2016a.

Visages du trans/posthumanisme a la lumiere de la question de l'humanisme. Revista Colombiana de Bioética, Bogotá v. 10, n. 2, p. 157-174, 20 jun. 2016b. Disponível em: <http://revistas.unbosque.edu.co/index.php/RCB/article/view/1763>. Acesso em: 13 set. 2018.

HUXLEY, J. New Bottles for New Wine. London: Chatto and Windus, 1957.

JONG, J. On Biotechnology, Theology, and the Human Sciences. Theology and Science, Berkeley, v. 16, n. 3, p. 343-352, 3 jul. 2018. Disponível em: <https://www. tandfonline.com/doi/full/10.1080/14746700.2018.1488527>. Acesso em: 30 set. 2018.

MAHER, D. F.; MERCER, C. R. (Org.). Religion and the implications of radical life extension. New York: Palgrave Macmillan, 2009.

MERCER, C.; MAHER, D. (Org.). Transhumanism and the Body: The World Religions Speak. 2014 edition ed. [S.1.]: Palgrave Macmillan, 2014.

MORE, M. Transhumanism: Toward a Futurist Philosophy. Extropy, Los Angeles n. 6 (Summer), 1990, p. 6-12. Revised June 1994 and 1996.

MURPHY, N. Bodies and Souls, or Spirited Bodies? New York: Cambridge University, 2006.

; STOEGER, W. R. Evolution and emergence systems, organisms, persons. New York: Oxford University Press, 2007.

NIETZSCHE, F. Genealogia da Moral: uma polêmica. 10. ed. São Paulo: Companhia das Letras, 2007.

PETERS, T. Theologians Testing Transhumanism. Theology and Science, Berkeley, v. 13, n. 2, p. 130-149, 3 abr. 2015. Disponível em: <http://www.tandfonline.com/doi/ full/10.1080/14746700.2015.1023524>. Acesso em: 22 set. 2018.

Imago Dei, DNA, and the Transhuman Way. Theology and Science, Berkeley, v. 16, n. 3, p. 353-362, 3 jul. 2018. Disponível em: <https://www.tandfonline.com/ doi/full/10.1080/14746700.2018.1488529>. Acesso em: 30 set. 2018.

RAHNER, K. Sämtliche Werke: Verantwortung der Theologie. Im Dialog mit Naturwissenschaften und Gesellschaftstheorie: BD 15. Freiburg: Verlag Herder, 2002. v. 15.

RUSSELL, R. J. et al. Neuroscience and the Person: Scientific Perspectives on Divine Action. Città del Vaticano : Berkeley (USA): Univ of Notre Dame Pr, 2000.

SANDEL, M. J. Contra a perfeição: ética na era da engenharia genética. [S.1.]: Civilização Brasileira, 2013. 
TIROSH-SAMUELSON, H. Facing the Challenges of Transhumanism: Philosophical, Religious, and Ethical Considerations, 2007. p. 16. Disponível em: <http://transhumanism.asu.edu/pdf/2007_news_challenges.pdf>. Acesso em: 11 set. 2018.

Transhumanist as a Secularist Faith. Zygon®, v. 47, n. 4, p. 710-734, dez. 2012. Disponível em: <http://doi.wiley.com/10.1111/j.1467-9744.2012.01288.x>. Acesso em: 22 set. 2018.

In Pursuit of Perfection: The Misguided Transhumanist Vision. Theology and Science, Berkeley, v. 16, n. 2, p. 200-222, 3 abr. 2018. Disponível em: <https://www. tandfonline.com/doi/full/10.1080/14746700.2018.1463659>. Acesso em: 11 set. 2018.

TRANSHUMANIST DECLARATION. Disponível em:

$<$ https://humanityplus.org/philosophy/transhumanist-declaration/>. Acesso em 23 set. 2018.

VILAÇA, M. M.; DIAS, M. C. M. Transumanismo e o futuro (pós-) humano. Physis: Revista de Saúde Coletiva, Rio de Janeiro v. 24, n. 2, p. 341-362, 2014. Disponível em: <http://www.scielo.br/scielo.php?script=sci_arttext\&pid=S0103$-73312014000200341 \& \operatorname{lng}=$ pt\&tlng=pt>. Acesso em: 23 set. 2018.

WOLFE, C. What is posthumanism? Minneapolis: University of Minnesota Press, 2010. Acesso em: 7 set. 2018.

ZABOROWSKI, H. Nach dem Posthumanismus: Bildung, Politik und der Stachel christlicher Erinnerung. Theologie der Gegenwart, Kevelaer v. 60, p. 269-281, 2017. Disponível em: <https://www.uni-erfurt.de/fileadmin/user-docs/Theologie_Gegenwart/3_zaborowski.pdf>. Acesso em: 21 set. 2018.

Artigo submetido em 25.08.2018 e aprovado em 30.11.2018.

Erico João Hammes é Doutor em Teologia Sistemática pela Universidade Gregoriana de Roma, com pós-doutorado pela Universidade de Tübingen, Alemanha. Professor Titular de Teologia Sistemática no Curso de Graduação e no Programa de Pós-Garaduação de Teologia da Pontifícia Universidade Católica do Rio Grande do Sul.

Orcid.org/0000-0002-6863-3811. E-mail:ehammes@pucrs.br.

Endereço: Av. Ipiranga, 6681, Prédio 5 - sala 407

90619-900 Porto Alegre - RS 